\title{
ROZWÓJ USTAWODAWSTWA DOTYCZĄCEGO ODPADÓW INNYCH NIŻ KOMUNALNE W POLSCE
}

\section{THE DEVELOPMENT OF LEGISLATION ON WASTE OTHER THAN MUNICIPAL WASTE IN POLAND}

http://dx.doi.org/10.12775/PPOS.2013.012

\section{STRESZCZENIE}

Prawna regulacja postępowania z odpadami innymi niż komunalne w Polsce pojawiła się ponad czterdzieści lat temu. Od tego czasu obowiązywały kolejno 4 podstawowe ustawy w tym zakresie. Obecnie problematyka ta jest regulowana przepisami ustawy z dnia 14 grudnia 2012 r. o odpadach, dziewięcioma innymi ustawami i znaczną ilością rozporządzeń wykonawczych.

\section{Słowa kluczowe}

Odpady, odpady inne niż komunalne, prawo o odpadach.

Dr hab. nauk prawnych, Katedra Prawa Górniczego i Ochrony Środowiska, Wydział Prawa i Administracji, Uniwersytet Śląski w Katowicach. 


\section{ABSTRACT}

It is forty years since legislation on waste other than municipal waste in Poland has been in force. During that time there were respectively four acts on waste. Currently, Polish waste law consists of new Act of $14^{\text {th }}$ December 2012 on waste, nine other acts and a substantial amount of regulations.

\section{Keywords}

Waste, waste other than municipal waste, waste law.

I.

Jednym z największych problemów współczesnej ochrony środowiska jest gospodarowanie odpadami. Dotyczy to zarówno substancji lub przedmiotów powstałych w gospodarstwach domowych (pozostałości o zbliżonym charakterze), określanych mianem odpadów komunalnych (nieczystości), jak i tych, które są wynikiem innych rodzajów aktywności człowieka, związanych przede wszystkim z prowadzoną działalnością gospodarczą). Odpady inne niż komunalne stanowią wynik nie tylko produkcji przemysłowej, ale również innych kategorii aktywności człowieka (np. pojazdy wycofane z eksploatacji czy też zużyty sprzęt elektryczny i elektroniczny). Można by, mając świadomość pojawienia się wątpliwości terminologicznych, określić je mianem „przemysłowych”. Warto jednak wiedzieć, iż obecnie przy analizie gospodarowania odpadami stosuje się kryteria związane nie tylko z miejscem ich powstania, ale również ze składem chemicznym, właściwościami fizycznymi czy wreszcie potencjalnym sposobem wykorzystania (odpady niebezpieczne, ulegające biodegradacji, opakowaniowe i inne). Dla uproszczenia dalszego wywodu określenie „odpad” będzie odnosiło się do wszystkich odpadów, z wyjątkiem komunalnych.

Kluczową rolę w skutecznym gospodarowaniu odpadami odgrywają odpowiednie uregulowania prawne. Jeśli w przy3/2013 padku odpadów komunalnych pojawiły się one stosunkowo 
wcześnie, to w odniesieniu do tych „przemysłowych” (innych niż komunalne) nastąpiło to na przestrzeni ostatnich 30-40 lat. Przedmiotem niniejszego opracowania nie jest bynajmniej kompleksowa analiza przepisów regulujących zasady gospodarowania odpadami. Nie będą również omawiane wątpliwości interpretacyjne dotyczące niektórych rozwiązań. Celem artykułu jest przybliżenie rozwoju prawodawstwa $\mathrm{w}$ analizowanym zakresie wraz ze wskazaniem występujących tu cech charakterystycznych i prawidłowości.

II.

Genezy prawnej regulacji postępowania z odpadami można dopatrywać się już na początku XX wieku. Warto tu wspomnieć choćby o Państwowej Zasadniczej Ustawie Sanitarnej z dnia 8 lutego 1919 r. ${ }^{1}$, która zobowiązywała „zarządy komunalne” do pieczy nad „[...] należytym usuwaniem wód zużytych i nieczystości [...]".

Podobnie „sanitarny” charakter miały rozporządzenia Naczelnego Nadzwyczajnego Komisarza do spraw walki z epidemjami [pisownia oryginalna]:

- w przedmiocie utrzymywania porządku w domach, na dziedzińcach, chodnikach i jezdniach w stoł. mieście Warszawie (bez daty wydania) ${ }^{2}$,

- z dnia 10 czerwca 1921 r. wydane w porozumieniu z Ministrem Spraw Wewnętrznych w przedmiocie utrzymania porządku w domach na dziedzińcach, chodnikach i jezdniach w gminach miejskich ${ }^{3}$.

Akty powyższe w sposób dość ogólny określały obowiązki władz lokalnych w zakresie ochrony przed nieczystościami, nakazy budowy i utrzymania odpowiednich urządzeń temu

1 Dziennik Praw Państwa Polskiego nr 15, poz. 207.

2 Dz.U. z 1921 r. Nr 14, poz. 90.

Dz.U. Nr 55, poz. 346. 
służących i wreszcie zakazywały zanieczyszczania „przestrzeni publicznej".

Próbą ujednolicenia regulacji, a także rozwinięcia i usystematyzowania prawnej problematyki ochrony środowiska przed zanieczyszczeniami było rozporządzenie Prezydenta RP z dnia 16 marca 1928 r. o usuwaniu nieczystości i wód opadowych ${ }^{4}$. Określała ona nieczystości jako „wydaliny ludzkie i zwierzęce, śmiecie i odpadki gospodarcze" (art. 2). Nakładała szereg obowiązków na gminy i władających nieruchomościami, dotyczących postępowania z powstałymi w wyniku bytowania człowieka odpadami, budowy urządzeń do ich gromadzenia, czy wreszcie postępowania ze ściekami komunalnymi. Obowiązek podłączenia do kanalizacji sanitarnej mógł być wprowadzony aktem prawa miejscowego. Jednocześnie rozporządzenie przewidywało delegację dla Ministra Spraw Wewnętrznych do określenia, w drodze przepisów sanitarnych, między innymi warunków, jakim powinny odpowiadać wszystkie publiczne i prywatne urządzenia do usuwania nieczystości i wód opadowych oraz zasad korzystania z nich. Delegacja ta została zrealizowana poprzez wydanie rozporządzenia Ministra Spraw Wewnętrznych i Opieki Społecznej z dnia 8 stycznia 1938 r. o korzystaniu z urządzeń wodociągowych oraz urządzeń do usuwania nieczystości i wód opadowych ${ }^{5}$, przy czym regulowało ono jedynie problem możliwości odłączenia dopływu wody.

Rozporządzenie Prezydenta RP określało również sankcje za naruszenie jego wymagań. Winni naruszenia wspomnianych przepisów podlegali karze grzywny do 1000 złotych i (lub) aresztu do 6 tygodni (art. 12).

Wspomniane akty regulowały problematykę, którą dzisiejszą nomenklaturą można określić jako gospodarowanie odpadami komunalnymi czy też utrzymanie czystości i porządku. Nie poruszały $\mathrm{w}$ praktyce zagadnień związanych z odpadami powstającymi w wyniku innych aktywności człowieka (zwłaszcza prowadzenia działalności gospodarczej). W tym ostatnim zakresie można wspomnieć co najwyżej o:

5 Dz.U. Nr 11, poz. 76. 
- okólniku Ministerstwa Skarbu T. 37 z dnia 21 grudnia 1934 r. w sprawie zaświadczeń wywozowych przy odprawie przesyłek odpadków tartacznych ${ }^{6}$,

- rozporządzeniu Ministra Spraw Wewnętrznych z dnia 6 grudnia 1924 r. wydanym w porozumieniu z Ministrem Przemysłu i Handlu, Ministrem Rolnictwa i Dóbr Państwowych, Ministrem Pracy i Opieki Społecznej i Ministrem Kolei o obrocie szmatami ${ }^{7}$.

W okresie powojennym regulacja dotycząca gospodarowania odpadami pierwotnie nie uległa większym zmianom. Nadal obowiązywało rozporządzenie z 1928 r. Poniekąd uzupełnieniem regulacji stało się wydane 12 lipca $1951 \mathrm{r}$. rozporządzenie Ministra Zdrowia w sprawie utrzymania porządku i czystości w nieruchomościach ${ }^{8}$. Co ciekawe, zostało ono wydane na podstawie ustawy z dnia 21 lutego 1935 r. o zapobieganiu chorobom zakaźnym i ich zwalczaniu' ${ }^{9}$. Rozporządzenie wprowadzało obowiązki między innymi w zakresie wyposażenia zamieszkałych nieruchomości w urządzenia przeznaczone do usuwania odpadów komunalnych. Zgodnie z jego §3 „W obrębie każdej zamieszkałej nieruchomości powinny znajdować się śmietnik, skrzynia na odpadki użytkowe, ustęp i trzepak, a na klatkach schodowych na każdym piętrze - spluwaczka".

Sytuacja w analizowanym zakresie uległa znaczącej zmianie z chwilą wejścia w życie ustawy z dnia 22 kwietnia 1959 r. o utrzymaniu czystości i porządku w miastach i osiedlach ${ }^{10}$. Regulowała ona między innymi postępowanie z nieczystościami rozumianymi jako (art. 2 ust. 1) „odpadki domowe, zmiotki uliczne, wydaliny ludzkie i zwierzęce oraz ścieki miejskie i wody opadowe na ulicach, placach i innych miejscach przeznaczonych do publicznego użytku". Akt ten określił między innymi zadania organów administracji prezydiów rad narodowych miast i osiedli w zakresie gospodarowania odpadami „komunal-

6 Mon. Pol. Z 1935 r. Nr 4, poz. 5.

7 Dz.U. z 1925 r. Nr 8, poz. 60.

8 Dz.U. Nr 40, poz. 306.

9 Dz.U. Nr 27, poz. 198.

10 Dz.U. Nr 27, poz. 167. 
nymi", obowiązki osób i jednostek sprawujących zarząd nieruchomości, czy wreszcie ogólne zasady działania komunalnych przedsiębiorstw oczyszczania.

Uchwalenie ustawy z dnia 22 kwietnia 1959 r. bez wątpienia należy uznać za niezwykle ważny moment w rozwoju prawnej regulacji szeroko rozumianego utrzymania czystości i porządku. Jednakże jej przedmiot (w analizowanym zakresie) ograniczał się do „nieczystości”. Nie zawierała ona żadnych rozwiązań dotyczących postępowania z innymi odpadami. Należy jednak zwrócić uwagę na jej art. 2 ust. 3, zgodnie z którym „sposób postępowania z odpadkami powstającymi w wyniku działalności produkcyjnej (np. przemysłowej, budowlanej), zepsutymi artykułami żywnościowymi i użytkowymi niepochodzącymi z gospodarstw domowych, oraz ze szlaką i popiołem z kotłowni centralnego ogrzewania normują przepisy szczególne, a w razie ich braku - przepisy wydane przez wojewódzkie rady narodowe (rady narodowe miast wyłączonych z województw)". Wśród dokumentów tego rodzaju można przykładem wskazać:

- uchwałę nr 258 Rady Ministrów z dnia 8 listopada 1974 r. w sprawie gospodarowania niemetalicznymi surowcami wtórnymi ${ }^{11}$,

- uchwałę nr 140 Rady Ministrów z dnia 18 lipca 1975 r. w sprawie premiowania za wykorzystanie odpadów przemysłowych z elektrowni, elektrociepłowni i ciepłowni $^{12}$,

- zarządzenie Przewodniczącego Państwowej Rady Gospodarki Materiałowej z dnia 27 sierpnia 1975 r. w sprawie zasad organizacji skupu niemetalicznych surowców wtórnych i obrotu nimi oraz określenia niemetalicznych surowców wtórnych objętych koordynacją branżową ${ }^{13}$,

- zarządzenie Ministra Gospodarki Materiałowej z dnia 23 grudnia 1976 r. zmieniające zarządzenie w sprawie zasad organizacji skupu niemetalicznych surowców

11 Mon. Pol. Nr 40, poz. 232.

12 Mon. Pol. Nr 24, poz. 152.

13 Mon. Pol. Nr 29, poz. 183. 
wtórnych i obrotu nimi oraz określenia niemetalicznych surowców wtórnych objętych koordynacją branżową ${ }^{14}$.

III.

Przełomem w rozwoju prawnej regulacji odpadami było uchwalenie, a następnie wejście w życie ustawy z dnia 31 stycznia 1980 r. o ochronie i kształtowaniu środowiska ${ }^{15}$. Jej rozdział 8 (dział II), zatytułowany „ochrona środowiska przed odpadami i innymi zanieczyszczeniami", zawierał rozbudowaną jak na owe czasy regulację postępowania, nie tylko jak dotychczas, z odpadami komunalnymi (nieczystościami), ale również tymi, które powstają w wyniku innych rodzajów działalności. Stąd też odpady zostały zdefiniowane jako „zużyte przedmioty oraz substancje stałe, a także nie będące ściekami substancje ciekłe, powstające w związku z bytowaniem człowieka lub działalnością gospodarczą, nieprzydatne, w miejscu lub czasie, w którym powstały, i uciążliwe dla środowiska" (art. 3 pkt 5 ustawy).

W pierwotnym brzmieniu ustawy regulacja dotycząca zasad postępowania $\mathrm{z}$ odpadami nie była zbyt rozbudowana. Zgodnie z jej art. 53 jednostki organizacyjne oraz osoby fizyczne prowadzące działalność gospodarczą, w wyniku której powstają odpady, zostały obowiązane chronić środowisko przed zanieczyszczeniem, niszczeniem lub innym ujemnym oddziaływaniem tych odpadów oraz do postępowania w sposób zapewniający ochronę środowiska przed odpadami, uwzględniając w pierwszej kolejności ich gospodarcze wykorzystanie. Dopiero te odpady, których nie można było wykorzystać gospodarczo, należało „zlikwidować, unieszkodliwić, gromadzić albo wylewać" w miejscach wyznaczonych na ten cel w planach zagospodarowania przestrzennego, w sposób zapewniający ochronę środowiska. Utrzymanie czystości i porządku (art. 57 ustawy)

14 Mon. Pol. Nr 3, poz. 26.

15 Tekst pierwotny Dz.U. Nr 3, poz. 6. Tekst jednolity Dz.U. z 1994 r. Nr 49, poz. 196 ze zm. 
polegało zaś na usuwaniu z terenów miast i wsi o zwartej zabudowie oraz z poszczególnych nieruchomości odpadów i innych zanieczyszczeń powstających w związku z bytowaniem człowieka i jego działalnością oraz na oczyszczaniu ze śmieci, odpadów, śniegu, lodu i błota ulic, dróg i placów publicznych.

Szczegółowe zasady postępowania z odpadami zostały określone w rozporządzeniu Rady Ministrów z dnia 30 września 1980 r. w sprawie ochrony środowiska przed odpadami i innymi zanieczyszczeniami oraz utrzymania czystości i porządku w miastach i wsiach ${ }^{16}$. Regulowało ono między innymi zasady wyznaczania miejsc gromadzenia odpadów (składowisk odpadów), gospodarczego wykorzystania odpadów grożących skażeniem lub zakażeniem oraz podstawowe zasady utrzymania czystości i porządku w gminach.

W czasie, gdy problematyka gospodarowania odpadami była regulowana przepisami ustawy o ochronie i kształtowaniu środowiska, należy odnotować cztery najważniejsze zmiany w tym zakresie. Pierwsza to wprowadzenie do rozdziału 8 ustawy z dnia 31 stycznia 1980 r. przepisów regulujących zasady transgranicznego przemieszczania odpadów. Obowiązek wprowadzenia tego typu rozwiązań wynikał z podpisania przez Polskę sporządzonej w Bazylei dnia 22 marca 1989 r. konwencji o kontroli transgranicznego przemieszczania i usuwania odpadów niebezpiecznych ${ }^{17}$. Drugą zmianą było uchwalenie ustawy z dnia 16 marca 1995 r. o zapobieganiu zanieczyszczaniu morza przez statki ${ }^{18}$. Należy odnotować także uregulowanie problematyki podziemnego składowania odpadów, co nastąpiło na mocy ustawy z dnia 4 lutego 1994 r. prawo geologiczne i górnicze ${ }^{19}$.

Największe jednak zmiany w analizowanym zakresie nastąpiły z wejściem w życie obowiązującej do dziś ustawy z dnia 13 września 1996 r. o utrzymaniu czystości i porządku w gminach $^{20}$. Określiła ona zadania gminy oraz obowiązki właścicie-

16 Dz.U. Nr 24, poz. 91 ze zm.

17 Dz.U. z 1995 r. Nr 19, poz. 88.

18 Dz.U. z 2012 r. Poz. 1244.

19 Tekst pierwotny Dz.U. Nr 27, poz. 96.

20 Dz.U. z 2012 r., poz. 391 ze zm. 
li nieruchomości, dotyczące utrzymania czystości i porządku, warunki wykonywania działalności w zakresie odbierania odpadów komunalnych od właścicieli nieruchomości i zagospodarowania tych odpadów oraz warunki udzielania zezwoleń podmiotom świadczącym usługi $\mathrm{w}$ zakresie uregulowanym w ustawie. Niezależnie od tego doszło do rozdzielenia regulacji prawnej problematyki postępowania z komunalnymi i innymi rodzajami odpadów.

IV.

Zmiany społeczno-gospodarcze, które nastąpiły na przełomie lat 80. i 90. XX w. spowodowały, iż obowiązująca w Polsce regulacja dotycząca gospodarowania odpadami okazała się wysoce niewystarczająca. Wspomniane wcześniej okoliczności, ale również zmiany systemu produkcji i konsumpcji spowodowały, iż niezbędne stało się uchwalenie nowego aktu regulującego powyższą problematykę w sposób kompleksowy. Warto wreszcie wspomnieć, iż na mocy art. 68 sporządzonego 16 grudnia 1991 roku w Brukseli Układu Europejskiego ustanawiającego stowarzyszenie między Rzeczpospolitą Polską z jednej strony a Wspólnotami Europejskimi i ich państwami członkowskimi z drugiej strony, Polska zobowiązała się do zbliżenia prawodawstwa krajowego do ustawodawstwa obowiązującego we Wspólnocie ${ }^{21}$. W analizowanym zakresie dotyczyło to przede wszystkim dyrektyw:

- Rady 75/442/EWG z dnia 15 lipca 1975 r. w sprawie odpadów ${ }^{22}$,

- Rady 91/689/EWG z dnia 1991 r. w sprawie odpadów niebezpiecznych ${ }^{23}$,

21 Dz.U. z 1994 r. Nr 11, poz. 38 ze zm.

22 Dziennik Urzędowy Wspólnot Europejskich Wydanie Specjalne z 2004 r. Rozdział 15, Tom 1, s. 23-25, ze zm.

23 Dziennik Urzędowy Wspólnot Europejskich Wydanie Specjalne z 2004 r. Rozdział 15, Tom 2, s. 78-86. 
- Parlamentu Europejskiego i Rady 94/62/WE z dnia 20 grudnia 1994 r. w sprawie opakowań i odpadów opakowaniowych ${ }^{24}$.

Pierwsza próbą uporządkowania stanu prawnego $w$ omawianym zakresie było uchwalenie dnia 27 czerwca 1997 r. ustawy o odpadach ${ }^{25}$. Określała ona postępowanie z odpadami rozumianymi jako „wszystkie przedmioty oraz substancje stałe, a także nie będące ściekami substancje ciekłe powstałe w wyniku prowadzonej działalności gospodarczej lub bytowania człowieka i nieprzydatne w miejscu lub czasie, w którym powstały" (w tym osady ściekowe).

Ustawa z 1997 r. przewidywała szereg instrumentów regulujących zapobieganie powstawaniu odpadów (jak choćby zezwolenie na ich wytwarzanie), wykorzystywanie odpadów (zarówno na cele przemysłowe, jak i nieprzemysłowe) i wreszcie unieszkodliwianie (w tym składowanie). Wprowadzała wreszcie bardzo rozbudowany system opłat ponoszonych zarówno za umieszczenie odpadów na składowisku, jak i za cały okres ich składowania (art. 26 ustawy). Było to rozwiązanie skrajnie nieuzasadnione z gospodarczego punktu widzenia. Podmiot składujący musiał bowiem ponosić opłaty z tego tytułu aż do dnia zakończenia eksploatacji składowiska lub jego części wydzielonej i wykonania prac rekultywacyjnych (art. 28). Wspomniany akt penalizował wreszcie wiele zachowań w gospodarowaniu odpadami jako przestępstwa.

Pierwsza kompleksowa ustawa o odpadach okazała się aktem wyjątkowo niespójnym i nieodpowiadającym potrzebom obrotu. Nie tylko w sposób nadmiernie (w sposób nieuzasadniony) komplikowała prowadzenie działalności gospodarczej, ale przewidziane $\mathrm{w}$ niej rozwiązania budziły spore wątpliwości co do ich skuteczności ${ }^{26}$. Niezależnie od tego wykazano, iż nawet

24 Dziennik Urzędowy Wspólnot Europejskich Wydanie Specjalne z 2004 r. Rozdział 13, Tom 13, s. 349-362.

25 Dz.U. Nr 96, poz. 592 ze zm.

26 G. Dobrowolski, Jest źle, może być gorzej. Projekt ustawy o odpadach, „Rzeczpospolita” z 19 III 1997 r. Por. także J. Jerzmański, Uwarunkowania prawne recyklingu odpadów, „Samorząd Terytorialny” z 1999 r., nr 10, s. 62-84 . 
w odniesieniu do definicji odpadów, ustawa ta była sprzeczna z dyrektywą 75/442/EWG ${ }^{27}$. Obowiązywała ona jednak jedynie do dnia 1 października 2001 r. Wówczas to weszła w życie ustawa z dnia 27 kwietnia 2001 r. o odpadach ${ }^{28}$. Wraz z ustawą $\mathrm{z}$ tego samego dnia Prawo ochrony środowiska stanowiła pakiet aktów, w zamiarze ustawodawcy, dostosowujących prawodawstwo polskie (w zakresie ochrony środowiska) do acquis communautaire.

Nowa ustawa, respektując postanowienia dyrektywy 75/442/EWG zdefiniowała odpady (art. 3 ust. 1 ustawy) jako „każdą substancję lub przedmiot należący do jednej z kategorii, określonych w załączniku nr 1 do ustawy, których posiadacz pozbywa się, zamierza pozbyć się lub do ich pozbycia się jest obowiązany" 29 . Postępowanie z tymi substancjami lub przedmiotami, zgodnie z art. 5 ustawy przyjęło postać trójelementowej sekwencji. Pierwszym jej elementem było zapobieganie ich powstawaniu (ograniczaniu ilości). Jego wyrazem był ogólny nakaz (art. 6 ustawy), skierowany do wytwórcy, stosowania takich sposobów produkcji lub form usług oraz surowców i materiałów, które zapobiegają powstawaniu odpadów lub pozwalają utrzymać na możliwie najniższym poziomie ich ilość, a także ograniczają negatywne oddziaływanie na środowisko lub zagrożenie życia lub zdrowia ludzi. Podstawowymi instrumentami w tym zakresie były:

- dokumenty „programujące” ochronę przed odpadami. Wśród nich warto wspomnieć krajowy plan gospodarki odpadami oraz wojewódzkie plany gospodarki odpadami (w pierwotnej wersji również plany gminne i powiatowe),

- decyzje reglamentujące powstawanie i niektóre kategorie postępowania z odpadami, w szczególności (art. 17)

27 A. Gubrynowicz, Pojęcia terminologiczne ustawy o odpadach $w$ świetle norm Unii Europejskiej, „Prawo i Środowisko” z 1999 r., nr 3, s. 66-72.

28 Tekst pierwotny Dz.U. Nr 62, poz. 628.

29 Ustawa wprowadziła dodatkowe kryteria, pozwalające wyróżnić odpady niebezpieczne, bioodpady, odpady komunalne, medyczne obojętne, ulegające biodegradacji, weterynaryjne i wreszcie z wypadków. 
pozwolenie na ich wytwarzanie (w ilości powyżej $1 \mathrm{Mg}$ odpadów niebezpiecznych rocznie lub powyżej 5 tysięcy $\mathrm{Mg}$ odpadów innych niż niebezpieczne rocznie), decyzja zatwierdzająca program gospodarki odpadami niebezpiecznymi (wytwarzanymi w ilości powyżej 0,1 Mg rocznie) czy wreszcie zezwolenie na prowadzenie działalności w zakresie zbierania i transportu odpadów (art. 28 ustawy).

Drugi etap sekwencji postępowania z odpadami w świetle przepisów ustawy z 2001 r. stanowił ich odzysk (w tym recykling). Ten pierwszy stanowił (art. 3 ust. 3 pkt 9 ustawy) „wszelkie działania, niestwarzające zagrożenia dla życia, zdrowia ludzi lub dla środowiska, polegające na wykorzystaniu odpadów w całości lub w części, lub prowadzące do odzyskania z odpadów substancji, materiałów lub energii i ich wykorzystania, określone w załączniku nr 5 do ustawy". Przez pojęcie recyklingu rozumiano zaś „odzysk, który polega na powtórnym przetwarzaniu substancji lub materiałów zawartych w odpadach $\mathrm{w}$ procesie produkcyjnym $\mathrm{w}$ celu uzyskania substancji lub materiału o przeznaczeniu pierwotnym, lub o innym przeznaczeniu, w tym też recykling organiczny, z wyjątkiem odzysku energii" (art. 3 ust. 3 pkt 14 ustawy).

Wreszcie, jeśli z przyczyn technicznych bądź ekonomicznych wytworzone odpady nie zostały poddane procesowi odzysku, winny być, w sposób bezpieczny dla środowiska unieszkodliwione. Przez to pojęcie rozumiano (art. 3 ust. 3 pkt 21): „poddanie odpadów procesom przekształceń biologicznych, fizycznych lub chemicznych określonym w załączniku nr 6 do ustawy w celu doprowadzenia ich do stanu, który nie stwarza zagrożenia dla życia, zdrowia ludzi lub dla środowiska”. Co istotne, zarówno odzysk, jak i unieszkodliwianie wymagało uzyskania zezwolenia właściwego organu ochrony środowiska (art. 26).

Ustawa z 2001 r. nie ograniczała się rzecz jasna tylko do wspomnianych wyżej instrumentów. Przewidywała cały szereg innych rozwiązań, związanych choćby z obowiązkami w zakresie sprawozdawczości, co do ilości wytworzonych odpadów, czy wreszcie uregulowań dotyczących postępowania z niektórymi 
ich rodzajami. W ograniczonym zakresie do postępowania z odpadami stosowano przepisy ustawy z dnia 27 kwietnia $2001 \mathrm{r}$. Prawo ochrony środowiska ${ }^{30}$ (np. w odniesieniu do pozwoleń czy też stosowania instrumentów finansowo-prawnych).

W okresie obowiązywania ustawy z 2001 r. Polska przystąpiła do Unii Europejskiej. Konieczne stało się zatem sukcesywne dostosowywanie naszego prawodawstwa do acquis communautaire. A początek XXI w. obfitował w szereg aktów prawnych w zakresie gospodarowania odpadami. Wśród najważniejszych można wskazać:

- dyrektywę Parlamentu Europejskiego i Rady 2000/53/ WE z dnia 18 września 2000 r. w sprawie pojazdów wycofanych z eksploatacji ${ }^{31}$,

- dyrektywę Parlamentu Europejskiego i Rady 2002/96/ WE z dnia 27 stycznia 2003 r. w sprawie zużytego sprzętu elektrotechnicznego i elektronicznego (WEEE) ${ }^{32}$,

- dyrektywę Parlamentu Europejskiego i Rady 2006/21/ WE z dnia 15 marca 2006 r. w sprawie gospodarowania odpadami pochodzącymi z przemysłu wydobywczego oraz zmieniającą dyrektywę 2004/35/WE ${ }^{33}$.

Dostosowując prawodawstwo polskie do wymagań aquis (oraz podjętych przez nasz kraj zobowiązań międzynarodowych), zostało przyjętych kilka ustaw regulujących postępowanie ze szczególnymi rodzajami odpadów. Uchwalono zatem ustawy z dnia:

- 11 maja 2001 r. o obowiązkach przedsiębiorców w zakresie gospodarowania niektórymi odpadami oraz o opłacie produktowej ${ }^{34}$,

30 Dz.U. z 2008 r. Nr 25, poz. 150 ze zm.

31 Dziennik Urzędowy Wspólnot Europejskich Wydanie Specjalne z 2004 r. Rozdział 15 Tom 5 s. 224-232.

32 Dziennik Urzędowy Wspólnot Europejskich Wydanie Specjalne z 2004 r. Rozdział 15 Tom 7 s. 359-374.

33 Dziennik Urzędowy Wspólnot Europejskich L 102, 11/04/2006 P. 0015-0034.

34 Tekst pierwotny Dz.U. Nr 63 poz. 639 ze zm. 
- 12 września 2002 r. o portowych urządzeniach do odbioru odpadów oraz pozostałości ładunkowych ze statków ${ }^{35}$,

- 30 lipca 2004 r. o międzynarodowym obrocie odpada$\mathrm{mi}^{36}$,

- 20 stycznia 2005 r. o recyklingu pojazdów wycofanych z eksploatacji ${ }^{37}$,

- 29 lipca 2005 r. o zużytym sprzęcie elektrycznym i elektronicznym ${ }^{38}$,

- 10 lipca 2008 r. o odpadach wydobywczych ${ }^{39}$,

- 24 kwietnia 2009 r. o bateriach i akumulatorach ${ }^{40}$,

- 13 czerwca 2013 r. o gospodarce opakowaniami i odpadami opakowaniowymi ${ }^{41}$.

W wyniku uchwalenia wyżej wymienionych aktów znacząco zmieniła się struktura polskiego prawodawstwa dotyczącego postępowania z odpadami. Od tego momentu można wyróżnić ustawę główną (ramową) określającą zasady gospodarowania wspomnianymi substancjami lub przedmiotami oraz odrębne akty regulujące postępowanie ze szczególnymi ich rodzajami. Można przyjąć, że powyższa struktura zaczęła odpowiadać modelowi obowiązującemu w Unii Europejskiej, gdzie można wyróżnić dyrektywę ramową (tzw. matkę) i dyrektywy szczegółowe (tzw. córki) ${ }^{42}$.

Warto także wspomnieć, iż dnia 5 kwietnia 2006 r. została uchwalona „nowa” dyrektywa Parlamentu Europejskiego i Rady 2006/12/WE w sprawie odpadów ${ }^{43}$. Jak się jednak przyjmuje,

35 Dz.U. Nr 166 poz. 1361 ze zm.

36 Dz.U. Nr 191, poz. 1956. Akt ten został zastąpiony ustawą z dnia 29 czerwca 2007 r. o międzynarodowym przemieszczaniu odpadów (Dz.U. Nr 124, poz. 859 ze zm).

37 Dz.U. Nr 25, poz. 202 ze zm.

38 Dz.U. Nr 180, poz. 1495 ze zm.

39 Dz.U. z 2013 r. poz. 1136.

40 Dz.U. Nr 79, poz. 666.

41 Dz.U. poz. 888.

42 Szerzej na ten temat patrz G. Dobrowolski, Europejskie prawo środowiska, „Ecausa” 2006, s. 116.

43 Dziennik Urzędowy Wspólnot Europejskich L 114, 27/04/2006 P. 0009- 
nie stanowiła ona zmiany jakościowej w zakresie gospodarowania wspomnianymi substancjami i stanowiła tekst ujednolicony dyrektywy z 1975 r. ${ }^{44}$. Dopiero kolejna dyrektywa, Parlamentu Europejskiego i Rady 2008/98/WE, z dnia 19 listopada 2008 r. w sprawie odpadów oraz uchylająca niektóre dyrektywy, spowodowała daleko idące zmiany w prawnych zasadach gospodarowania odpadami w UE. Akt ten nie tylko skonsolidował prawodawstwo Unii Europejskiej w omawianym zakresie i zastąpił inne, starsze, dyrektywy. Wprowadził również szereg nowych rozwiązań dotyczących między innymi zmiany hierarchii postępowania z odpadami, pojęcia produktu ubocznego czy też możliwości ponownego wykorzystania ${ }^{45}$.

Dyrektywa 2008/98/WE została implementowana do polskiego porządku prawnego dopiero ustawą z dnia 14 grudnia 2012 r. o odpadach (dalej „u.odp.”) ${ }^{46}$. Ta ostatnia w sposób dość znaczący zmodyfikowała obowiązujący w Polsce system gospodarowania odpadami. Zachowując dotychczasową definicję odpadu, wprowadziła pięciostopniową hierarchię (sekwencję) postępowania z nimi. Składają się na nią:

1) zapobieganie powstawaniu odpadów,

2) przygotowywanie do ponownego użycia,

3) recykling,

4) inne procesy odzysku,

5) unieszkodliwianie.

W praktyce największe znaczenie (jak i w poprzednim stanie prawnym) mają dwa rodzaje działań, jakimi są odzysk i unieszkodliwianie. Tym pierwszym, zgodnie z art. 3 ust. 1 pkt 14 ustawy jest ,jakikolwiek proces, którego głównym wynikiem jest to, aby odpady służyły użytecznemu zastosowaniu przez zastąpienie innych materiałów, które w przeciwnym przypadku zostałyby użyte do spełnienia danej funkcji lub w wyniku którego odpady są przygotowywane do spełnienia takiej funkcji

44 B. Draniewicz, J. Jerzmański, S. Moczko-Wdowczyk, J. Rotko, J. Sommer [w:] Instytucje prawa ochrony środowiska. Geneza, rozwój, perspektywy, red. W. Radecki. Warszawa 2010, s. 72.

45 Dziennik Urzędowy Unii Europejskiej L 312, 22/11/2008 P. 0003-0030.

46 Dz.U. z 2013 r., poz. 21. 
w danym zakładzie lub ogólnie w gospodarce". Szczególną postacią odzysku jest recykling polegający na działaniu, w ramach którego odpady są ponownie przetwarzane na produkty, materiały lub substancje wykorzystywane w pierwotnym celu lub innych celach; obejmuje to ponowne przetwarzanie materiału organicznego (recykling organiczny), ale nie obejmuje odzysku energii i ponownego przetwarzania na materiały, które mają być wykorzystane jako paliwa lub do celów wypełniania wyrobisk (art. 3 ust. 1 pkt 23 u.odp.). W praktyce odzysk polega więc na wykorzystaniu substancji zgodnie z prawem, w taki sposób, iż utraci ona status odpadu. Może to nastąpić w sytuacji, gdy w wyniku powyższych procedur odpad „staje się" przedmiotem lub substancją spełniającą łącznie następujące warunki (art. 14 ust. 1 u.odp. $)^{47}$ :

a) jest powszechnie stosowany do konkretnych celów,

b) istnieje rynek takich przedmiotów lub substancji lub popyt na nie,

c) dany przedmiot lub substancja spełniają wymagania techniczne dla zastosowania do konkretnych celów oraz wymagania określone $\mathrm{w}$ przepisach i w normach mających zastosowanie do produktu.

Niewyczerpujący wykaz procesów odzysku zawiera załącznik I ustawy o odpadach.

Inaczej sytuacja wygląda w przypadku unieszkodliwiania. Jest to proces niebędący odzyskiem, nawet jeżeli wtórnym skutkiem takiego procesu jest odzysk substancji lub energii (art. 3 ust. 1 pkt 30 u.odp.). Pomimo ułomności tej ostatniej definicji (można bowiem dojść do wniosku, iż unieszkodliwianiem odpadów jest np. zapobieganie ich powstawaniu) należy stwierdzić, iż proces powyższy będzie polegać przede wszystkim na różnych formach składowania odpadów, ich przekształcanie termiczne, czy wreszcie inne procesy fizyczne, biologiczne i chemiczne.

Warto wreszcie wspomnieć, iż nowa ustawa wprowadziła pojęcie produktu ubocznego (art. 10 u.odp.). Za taki może zostać uznany przedmiot lub substancja, powstające w wyniku

47 Substancja lub produkt musi również spełniać wymagania przewidziane przepisami Unii Europejskiej. 
procesu produkcyjnego, którego podstawowym celem nie jest ich produkcja,,jeżeli są łącznie spełnione następujące warunki:

1) dalsze wykorzystywanie przedmiotu lub substancji jest pewne,

2) przedmiot lub substancja mogą być wykorzystywane bezpośrednio bez dalszego przetwarzania, innego niż normalna praktyka przemysłowa,

3) dany przedmiot lub substancja są produkowane jako integralna część procesu produkcyjnego,

4) dana substancja lub przedmiot spełniają wszystkie istotne wymagania, w tym prawne, w zakresie produktu, ochrony środowiska oraz życia i zdrowia ludzi, dla określonego wykorzystania tych substancji lub przedmiotów i wykorzystanie takie nie doprowadzi do ogólnych negatywnych oddziaływań na środowisko, życie lub zdrowie ludzi.

Rozstrzygnięcie $\mathrm{w}$ przedmiocie uznania przedmiotu lub substancji za produkt uboczny podejmuje marszałek województwa poprzez niezgłoszenie sprzeciwu w drodze decyzji.

Ustawa z 2012 r. reguluje znacznie szersze spektrum aspektów postępowania z odpadami niż przedstawione wyżej. Jest to akt liczący łącznie 253 artykuły. Brak tu jednak miejsca na dokonanie ich głębszej analizy. Nie to jest zresztą przedmiotem niniejszego opracowania.

\section{V.}

Przeprowadzona wyżej analiza pozwala na wyciągnięcie kilku wniosków dotyczących rozwoju i struktury regulacji prawnej dotyczącej gospodarowania odpadami „przemysłowymi” w Polsce. Po pierwsze, można wyróżnić trzy okresy rozwoju prawodawstwa w tym zakresie. Pierwszy, do wejścia w życie ustawy z dnia 31 stycznia 1980 r. o ochronie i kształtowaniu środowiska charakteryzował się praktycznie brakiem uregulowań (rangi ustawowej) dotyczących postępowania z nimi. W praktyce regulacja w tym zakresie ograniczała się do kilku aktów pod- 
stawowych, czasami niemających nawet charakteru przepisów powszechnie obowiązujących. Drugi etap rozwoju ustawodawstwa rozpoczęło uchwalenie i wejście w życie ustawy z dnia 31 stycznia 1980 r. o ochronie i kształtowaniu środowiska. Pojawiła się wówczas po raz pierwszy regulacja ustawowa odnosząca się stricte do gospodarowania odpadami „przemysłowymi”. Trzeci (obecny) etap rozpoczęło uchwalenie ustawy z dnia 27 czerwca 1997 r. ustawy o odpadach. Tu nastąpiło swego rodzaju „usamodzielnienie” analizowanej problematyki.

Struktura współczesnego (polskiego) prawodawstwa określającego podstawy postępowania z odpadami innymi niż komunalne, jest zbudowana według wzorca obowiązującego w Unii Europejskiej. Ustawa z dnia 14 grudnia 2012 r. ma charakter regulacji ramowej, wprowadzając z jednej strony ogólne zasady postępowania $\mathrm{w}$ analizowanym zakresie, $\mathrm{z}$ drugiej nakładając szereg obowiązków o charakterze szczegółowym (jak choćby w zakresie wydawania zezwoleń, czy też związanych ze sprawozdawczością). Uzupełnieniem (ale i rozwinięciem) są wymienione wyżej ustawy regulujące postępowanie ze szczególnymi rodzajami odpadów. Są to wspomniane ustawy z dnia:

- 11 maja 2001 r. o obowiązkach przedsiębiorców w zakresie gospodarowania niektórymi odpadami oraz o opłacie produktowej,

- 12 września 2002 r. o portowych urządzeniach do odbioru odpadów oraz pozostałości ładunkowych ze statków,

- 20 stycznia 2005 r. o recyklingu pojazdów wycofanych z eksploatacji,

- 29 lipca 2005 r. o zużytym sprzęcie elektrycznym i elektronicznym,

- 29 czerwca 2007 r. o międzynarodowym przemieszczaniu odpadów,

- 10 lipca 2008 r. o odpadach wydobywczych,

- 24 kwietnia 2009 r. o bateriach i akumulatorach.

Oprócz powyższych można tu jeszcze wskazać na inne akty prawne, gdzie problematyka gospodarowania odpadami 
jest uregulowana fragmentarycznie. Przykładem może tu być choćby ustawa z dnia 29 listopada 2000 r. Prawo atomowe ${ }^{48}$.

W chwili wejścia w życie ustawy z dnia 31 stycznia 1980 r. o ochronie i kształtowaniu środowiska problematyka gospodarowania odpadami „przemysłowymi” była regulowana 5 artykułami i jednym rozporządzeniem. W chwili obecnej, w zakresie gospodarki odpadami możemy wskazać 10 ustaw zawierających, pomijając przepisy końcowe i przejściowe, ponad 600 artykułów. Należy tu jeszcze wspomnieć o dziesiątkach aktów wykonawczych, o objętości często kilkunastu stron dziennika ustaw. Można rozważać więc, czy nie doszło do ukształtowania się nowej dziedziny prawa, którą można by określić „prawem gospodarowania odpadami” albo „prawem odpadowym”.

Przyrost materii ustawowej w analizowanym zakresie jest spowodowany przede wszystkim koniecznością dostosowania prawodawstwa polskiego do acquis communautaire. Można dojść do wniosku, iż organy Unii Europejskiej za punkt honoru postawiły sobie przeregulowanie gospodarki odpadami, i chyba im się to udało. Zwłaszcza że część aktów prawnych nie jest nakierowana na zwalczanie przyczyn stanów niepożądanych, lecz tylko ich skutków ${ }^{49}$.

Niestety ilość przepisów określających zasady gospodarowania odpadami „przemysłowymi” nie przekłada się na ich jakość. Ustawy regulujące powyższą problematykę były uchwalane na przestrzeni kilkunastu lat. Ich poziom legislacyjny jest bardzo różny. $\mathrm{W}$ odniesieniu do części z nich można także wykazać brak spójności pomiędzy poszczególnymi aktami oraz ich konkretnymi przepisami.

48 Dz.U. z 2012 r. poz.264 ze zm.

49 Przykładem może być tu gospodarowanie zużytym sprzętem elektrycznym i elektronicznym. Przyczyną powstawania ogromnych ilości tego typu odpadów jest bardzo niska trwałość urządzeń, a dyrektywa WEEE tej problematyki w ogóle nie dostrzega. 


\section{BIBLIOGRAFIA}

Dobrowolski G., Europejskie prawo środowiska, „Ecausa” 2006.

Dobrowolski G., Jest źle, może być gorzej. Projekt ustawy o odpadach, „Rzeczpospolita” z 19 III 1997 r.

Gubrynowicz A., Pojęcia terminologiczne ustawy o odpadach $w$ świetle norm Unii Europejskiej, „Prawo i Środowisko” 1999, nr 3, s. 66-72 .

Instytucje prawa ochrony środowiska. Geneza, rozwój, perspektywy, red. W. Radecki. Warszawa 2010.

Jerzmański J., Uwarunkowania prawne recyklingu odpadów, „Samorząd Terytorialny" 1999, Nr 10, s. 62-84.

Kontakt e-mail:

grzegorz.dobrowolski@onet.eu 